the municipality of Freiburg in Germany refused to accept as legal proof of debt entries made in Arabic numerals.

The diagonal lines canceling the entries indicated that the latter had been transferred to a new ledger or had been balanced out.

The entries are crowded together because both debit and credit are on the same page. This differs from the Venetian system as described by Pacioli and as exemplified by carefully and neatly kept Venetian books of the fifteenth and sixteenth centuries. In Venice the debits and credits were entered on different pages facing each other and each entry occupied one or two long lines, instead of being crowded into a narrow space as in the Genoese books.

Venice took the lead in the development of the science of bookkeeping and set the style for most of Italy and northern Europe. Indeed bookkeeping by double entry was popularly known in the sixteenth century as "bookkeeping according to the method of Venice."

But the question of the time and place of the origin of doubleentry bookkeeping in Italy is raised by the fact that the oldest known example of double entry is not Venetian but Genoese - the Genoese stewards' cartulary of $134^{\circ}$, and that the second oldest example is a Florentine ledger of I39c, kept according to the Venetian system, which belonged to the Company of Averardo de' Medici, a money-changer. The question may never be answered because so few early accounts have survived. The oldest Venetian ones date from I 406. Since the Genoese and Venetian systems differ somewhat, they may have developed simultaneously and independently. Did the Italians inherit a Roman system or a Byzantine one, or did they really invent bookkeeping by double entry? Was double entry first used in official accounts and then adopted for business accounts, or was the reverse the case? At present the evidence is too limited to afford solutions, but further exploration in the Italian archives may result in partial or complete solutions of these and similar interesting problems connected with the early history of modern methods of accountancy.

\title{
Research on the Medici Manuscripts
}

\section{Selfridge Collection}

IT HAS proved to be.a difficult task to decipher the Medici records, particularly the account books. Three articles of agreement, various letters, and the oldest account book have been transcribed and 
translated. These materials throw not a little light on the trade of Florence with the Levant. It is expected that the work already begun by Dr. Gertrude Richards will be finished during the coming academic year.

A new study has been begun by Dr. Florence Edler. This is a Glossary of Mediaeval Italian Terms of Business. For this work, the Medici records will be invaluable. Though somewhat later than the Medici records, the Barberini documents donated by $\mathrm{Mr}$. Edward J. Frost promise to be of great assistance. Dr. Edler's thesis on the Silk Trade of Lucca is an excellent beginning for the study in question.

The new Glossary is being compiled under the auspices of the Mediaeval Academy of America and under the direction of Professor N. S. B. Gras. From Italy, Europe, and later America, got their business terms and practices. With these went Italian civilization. In the new study, business records promise to be of the greatest assistance. Already the foresight of Mr. H. Gordon Selfridge, who purchased the Medici documents in London, has been abundantly justified.

\section{A Glimpse of Post-War Richmond}

A Northern man's impression of Richmond and Petersburg, only two months after the surrender of Lee, is preserved in a letter to Frances Stabler, daughter of James P. Stabler, who was Superintendent of Construction on the Baltimore and Ohio Railroad in 1831 and ' 32 . The friend who is writing begins with a eulogy on Lincoln, whose assassination is the news of the hour, and then continues with an account of a trip to Richmond which he had just made with his father and someone he refers to as "Brother Eddy," whether in the literal or the Quaker sense is not clear.

"Leaving here on the 7 th day afternoon on the Ellie Knight," he writes, "we took the outside passage being 24 hours at Sea and arrived at Fortress Monro at 5 A.M. 2nd day morning witnessing a magnificent sunrise on the ocean just as we entered Hampton Rhoads.

"Our first stoppage was at Norfolk to land and see the town.

"Some of our party visited the Navy Yard (Gossport) and were taken by the commandant in a small steamer all round the Harbour to see the monitors \&c. We had a good view of these and the "Alabama" captured from the Rebs. ... 